\title{
Penal and Non-Penal Approaches to the Legal Enforcement of Child Marriage: A Political Analysis of Criminal Law
}

\author{
Sri Ismawati
}

Faculty of Law, Universitas Tanjungpura, Indonesia

\begin{abstract}
This study is directed to examine the issue of child marriage from the perspective of criminal politics. Criminal political perspective child marriage is a perspective that not only sees the problem of child marriage solely as a matter of criminal law, but also tries to look at the problem of child marriage from a non-legal perspective. By using normative and juridical approach, the results showed that the perspective of politics of criminal law of child marriage is to see the problem of child marriage solely as a matter of criminal law, but also tries to look at the problem of child marriage from a non-legal perspective. The politics of criminal law with a penal approach can be done by using integrative formulation, revision, criminalization, penalization of child marriage, law enforcement against criminal acts related to child marriage, encouraging the making of Regional Regulations, Governor Regulations or Regulations of Regents. On other hand, the non-penal approach is by empowering the role of parents by conducting education, education and self-esteem; empowering the role of religious leaders, community leaders, traditional leaders; family economic empowerment, education empowerment and integral policy models
\end{abstract}

Keywords: Penal and non-penal approaches, legal enforcement, child marriage, politics of law, criminal law.

\section{INTRODUCTION}

In Indonsia, Law Number 1 of 1974 requires age restrictions for men and women. Article 7 of the Marriage Law defines that marriage is only permitted if the male has reached the age of 19 years and the female has reached the age of 16 years. In the case of a dispute, it may be requested from the court or other official appointed by both male and female parents. This means that marriage under the required age of 19 years and 16 years is possible as long as there is permission from parents as regulated in Article 6 Paragraph (2), or any dispensation from the court or other official appointed by both parents. Determination of the age limit of 19 years for men and 16 years for women certainly has its own considerations relating to spiritual, biological, psychological and social considerations. Although legally the law opens opportunities for underage marriages, parents and/or parties who have the authority to approve child marriages, try to avoid child marriages.

The phenomenon of children in any part of the world is felt as a separate problem, which requires the active involvement of the State, society and even parents. Various reasons have been identified and inventoried as problems that require policy priorities. The impact of child marriage is more felt or experienced by the children themselves, especially girls, also on the children they deliver. Girls are allegedly more likely to feel the effects related to education being interrupted,

*Address correspondence to this author at the Faculty of Law, Universitas Tanjungpura, Indonesia; E-mail: sri.ismawati@hukum.untan.ac.id psychologically due to dropping out of school, becoming a young mother or in the event of a divorce, biological effects - health when giving birth at a young age, threats of violence and other impacts. The impact of early marriage as stated above has the potential to cause violations of children's rights, violate the Convention on the Rights of the Child, the Universal Declaration of Human Rights, the Convention on the Elimination of All Forms of Discrimination Against Women (CEDAW) and national laws such as the Child Protection Act, Child Welfare, and the Criminal Code.

Taking into account the various impacts and violations experienced by children when they are married before the age required by law, it is important to provide certainty and protection for the actions of parents or anyone so that children are not married when they are children or young. Protection of children's rights has actually been guaranteed as normative in the child protection law. The prohibition on marrying off children is included in Part Four Obligations and Responsibilities of Family and Parents, Article 26 reads as follows: Article 26 states that parents have the obligation and responsibility to care for, maintain, educate, and protect children, to develop children according to their abilities, talents, and interests, prevent marriages at the age of children and provide character education and instill the value of character in children. In the event that parents are absent, or their whereabouts are unknown, or for some reason they cannot carry out their obligations and responsibilities, the obligations and responsibilities referred to in paragraph (1) may be transferred to the Family, which is carried out in accordance with 
statutory provisions. Even though various international and national legal instruments provide signs and prohibitions on child marriages, child marriages are still often found in many regions of Indonesia. The existence of limited criminal law instruments in the Penal Code is less supported by the regulation of sanctions that are inherently inherent in every law that regulates children. The child protection law, for example, does not yet stipulate sanctions for parents or anyone who carries out and/or facilitates child marriage as stipulated in Article 26, unless there is an indication of exploitation. Besides that, the issue of child marriage is not only a matter of law, but also relates to issues of religion, education, welfare, economic, social and even community culture. This research is directed to examine the issue of child marriage from the perspective of politics of law of criminal law. This perspective child marriage is a perspective that not only sees the problem of child marriage solely as a matter of criminal law, but also tries to look at the problem of child marriage from a non-legal perspective.

\section{CHILDREN'S RIGHTS AND CHILD PROTECTION PRINCIPLES}

In Indonesia the phenomenon of child marriage is also rife, especially in rural areas. According to data from the United Nations Children's Fund (UNICEF), Indonesia is one of the countries contributing to the seventh early marriage in the Southeast Asian region. The Jakarta Central Statistics Agency in cooperation with the United Nations Children's Fund (UNICEF), in the 2008-2012 Susenas Report and the results of the 2010 Population Census mentioned (Badan Pusat Statistik\&UNICEF, 2016) that the prevalence of child marriage is involving a very large and surprising number of child brides. Based on data from the Indonesian Democracy and Health Survey, 17 percent of women aged 20-24 years who had been married, married before the age of 18 years. This means that 340,000 marriages in Indonesia occur in girls under the age of 18. Meanwhile, based on 2012 Susenas data, 25 percent of women aged 20-24 years who have never married, married before the age of 18 with the highest prevalence found in rural areas. Furthermore, analysis of Susenas data shows that the declining trend in the prevalence of child-age marriages in Indonesia only occurred from 2008 to 2010 . The prevalence of child-age marriages increased in 2011 and then stagnated in 2012.

There are no strict restrictions on the term child both in regulation and in physical, social and psychological development, so the use of the term child in some regulations and literature also includes the term adolescent. In general, people define adolescence as a transition period between childhood and adulthood (1120 years). The concept of adolescents is not from the field of law, but comes from other fields of social sciences such as anthropology, sociology, psychology and pedagogy, so that the concept of adolescents is not well known in Indonesian law.

In the law, the definition of a child is oriented to age restrictions with rank or distance adjusted to the need for legal arrangements such as, Law Number 1 of 1974 concerning Marriage, Law Number 4 of 1979 concerning Child Welfare, Civil Code Article 330, Compilation of Islamic Law, Law Number 11 Year 2012 concerning the Criminal Justice System for Children, and Law Number 11 Year 2012. From the formulation of various laws above, it appears that the definition of children is all related to a certain age range. Conceptual understanding of children can be seen from the understanding of adolescents, which when viewed from the age limit of children according to the law are included in the age range of adolescents conceived by the United Nations through the WHO (World Health Organization), which provides adolescent definition to adolescents in 3 biological, psychological and socioeconomic criteria, so that adolescents are defined as a period in which an individual develops from the first time he shows secondary sexual signs until he reaches sexual maturity; the individual experiences psychological development and identification patterns from childhood children become adults; there is a transition from full socioeconomic dependence to a relatively more independent state (Muangman, 1980).

From health problems (women's fertility problems and premature pregnancy), WHO sets the age limit of 10-20 years as a limit for the age of adolescent women and men, where the age of 10-14 years into the category of early adolescents and ages 15-20 years into the category of late adolescents. In Indonesia, defining Indonesian youth is as difficult as determining teenage age in general. As a general guideline, it can be used the benchmark age 11-12 years and unmarried for Indonesian adolescents with the consideration that age 11 is the age where in general secondary sexual signs begin to appear; in many Indonesian communities, the age of 11 years is considered to be of puberty, both according to tradition and religion so that they are no longer treated as children; at that age there are signs of perfecting mental development such as the achievement of self- 
identity (achievement of the genital phase of psychosexual development) and the peak of cognitive and moral development of the 24-year age limit is the maximum limit to provide opportunities for those who reach the age limit is still rely on parents, do not have full rights as an adult traditionally do not have their own opinions and so on (Santrock, 2003).

The consideration of these various aspects ultimately becomes an argumentative that children should be protected and guaranteed their rights by parents, society and also the State. As a manifestation of that responsibility the state guarantees constitutional welfare of children in the 1945 Constitution. In a hierarchical manner, various legal products that are the basis of policies and guidelines for treating Indonesian children are issued and ratified, starting with national legal products and international legal products that have been ratified by Indonesia. To provide normative protection for children, Indonesia has no less than 15 legal products, both specifically regulating children or not, including Law No. 4/1979 concerning Child Welfare, Law No.3/1997 concerning Children's Courts, Law No. 23/2002 on Child Protection, Law No. 23/2004 concerning Elimination of Domestic Violence, Law No.13/2006 concerning Protection of Witnesses and Victims, Law No. 21/2007 concerning Eradication of Trafficking in Persons, etc. It also includes various international instruments that have been ratified by Indonesia, including the Convention on the Rights of the Child: ratification through Presidential Decree No. 36/1990, Convention No. ILO 138/1973: ratification through Law No.2 of1999 concerning age limits for working children, ILO Convention No. 182: ratification through Law No.1 of 2000 concerning the Prohibition of the Worst Forms of Child Labor, etc. Besides that, various international instruments in the form of international principles, standards, guidelines contained in various UN resolutions were also born as a manifestation of the world concern for the fate of children, including: UN Resolution 40/33 of 1985 concerning UN Standard Minimum Rules for the Administration of Juvenile Justice, UN Resolution 43/121 of 1988 concerning The use of Children in the Traffic Traffic in Narcotic Drugs, United Nations Resolution No 45/112 of 1990 concerning the UN Guidelines for the Prevention of Juvenile Delinquency. All of this aims to ensure that Indonesian children receive adequate protection from various policies and ill-treatment of people, society and the country.

Law Number 23 of 2002 has implicitly provided a clear legal basis and scope for the guarantee of protection of the child in question. Article 1 formulates that child protection is all activities to guarantee and protect children and their rights so that they can live, grow, develop, and participate, optimally in accordance with human dignity and dignity, and receive protection from violence and discrimination. The formulation of the principles of protection includes aspects of protection of children's rights and freedoms, protection of children in the judicial process, protection of children's welfare, protection of children in the matter of detention and deprivation of liberty, protection of children from all forms of exploitation, protection of street children, protection of children from the consequences of war and armed conflict; protection of children against acts of violence; and protection of children's rights and freedom, protection of children's welfare.

Protection of children from all forms of exploitation and protection of children against acts of violence, can be an umbrella of protection for children married under the required age. These four types of protection represent the rights that should be safeguarded and given to children, such as the right to life, to grow and participate in accordance with dignity; the right to education; the right to express opinions and to be heard, accept, seek and provide information in accordance with their intelligence; the right to rest and to take advantage of free time and socialize; The right to protection and treatment from: discrimination, exploitation, both economic and sexual, abandonment, cruelty, violence and persecution, injustice, and other wrongdoing.

\section{IMPACT AND FACTORS THAT CAUSE CHILD MARRIAGE AND THE URGENCY OF ITS PROTECTION}

Various studies have been conducted to determine empirically the impact on children who are married at the age of the child. UNICEF is one of them who has conducted the research in question and found several impacts. For married girls, child-age marriages cause pregnancy and early childbirth, which are associated with high mortality and abnormal conditions for the mother because the daughter's body is not fully ripe for childbirth. Girls face a much higher risk of complications associated with childbirth, such as obstetric fistula, infection, heavy bleeding, anemia and eclampsia. Marriage at a young age burdens daughters with the responsibilities of being a wife, sex partner, and mother, roles that should be performed by adults, who are not ready to be performed by girls. This marriage also creates a great psychological and 
emotional burden on them. There is also an age gap, where girls are much younger than their partners.

According to one report, 85 percent of girls in Indonesia end their education after they are married, but the decision to marry and end education can also result from lack of employment opportunities. There are schools in Indonesia that refuse married girls to go to school. Other studies also show that child brides have a greater chance of experiencing sexual, psychological and emotional physical violence, and social isolation, which is a result of their lack of status and power in their household.

For children born, child-age marriages have intergenerational impacts. Babies born to girls who marry at the age of children have a higher risk of death, and are twice as likely to die before the age of 1 year compared to children born to a mother who is in her twenties. Babies born to child brides also have a higher chance of being born prematurely, with low birth weight, and malnutrition. Children born to mothers aged less than 19 have a 30-40 percent increased risk of stunting for 2 years and failure to complete secondary school.

For the community, child-age marriage not only underlies, but also encourages gender inequality in society. Child-age marriages can lead to a continuous cycle of poverty, increased illiteracy, ill health to future generations, and depriving the productivity of the wider community both in the short and long term. Arivia $(200 \%)$, Saraswati (2009) showed that children who are married at a young age carry a greater risk of contracting venereal disease and HIVIAIDS. These children do not have the power to negotiate about safe sex (safe sex), besides being vulnerable to acts of domestic violence. As many as $67 \%$ of children who are forced into marriage experience violence, compared to $47 \%$ of married adult women (Saraswati, 2009).

The rise of the phenomenon of child marriage in various parts of the world is caused by various factors that are diverse and complex. The poverty factor is one of the factors that is considered the most dominant in addition to cultural factors, social status, religion and unwanted pregnancy. Gender equality factors based on a collaboration research from Central Bureau of Statistics \& UNICEF (2016) also contribute to child marriages, as reported that child age marriages are caused by gender inequality and how women and girls are viewed in society, communities and families. If most assume that women's roles are as wives and mothers, they are more likely to be married off at a young age.

The poverty factor is also a concern for become an important background. This practice is still encountered, among others due to poverty. In some poor countries, girls are targeted for sale or marriage so parents are freed from economic burdens. Another reason is the caste, tribal interests and economic and political power so that their married children can strengthen their offspring and social status. Pregnancy before marriage is also a trigger factor to marry off their children so as not to bear the shame of the family. In addition, weak state law is also one of the reasons why children are not protected from this practice.

Various factors cause child marriage as seen from expert opinion and the results of Central Bureau of Statistics \& UNICEF (2016), it can be said as a causal symptomatic that requires therapeutic methods in its response. This causal symptomatic indicates that child marriage does not only occur in the jurisdiction as a product of State policy in a set of values and norms, but is also related to non-legal issues so that it is theoretically possible. Therapeutic method is one of the approaches that is very possible to do, namely to carry out a comprehensive and integral policy approach in dealing with child marriage.

\section{POLITICAL APPROACH OF CRIMINAL LAW AGAINST THE PHENOMENON OF CHILD MARRIAGE}

The politics of law of criminal law on child marriage is to make policies and/or decisions about the most effective and most efficient ways that are set to achieve the goals agreed collectively to prevent, minimize, overcome and even eliminate child marriage (Arief, 2008; Arief, 2011). Sudarto (1981) gives three meanings regarding politics of law of criminal law or criminal policy. In a narrow sense, it is the whole principle and method that form the basis for a reaction to a criminal law violation. In a broad sense, is the overall function of the law enforcement apparatus, including the workings of the court and police. In the broadest sense, is the whole policy, which is carried out through legislation and official bodies, which aims to enforce the central norms of society.

Sudarto (1983) gives a brief definition of politics of criminal law is a rational effort from the community in tackling crime. This definition is the same as stated by Marc Ancel, who formulates the politics of criminal law 


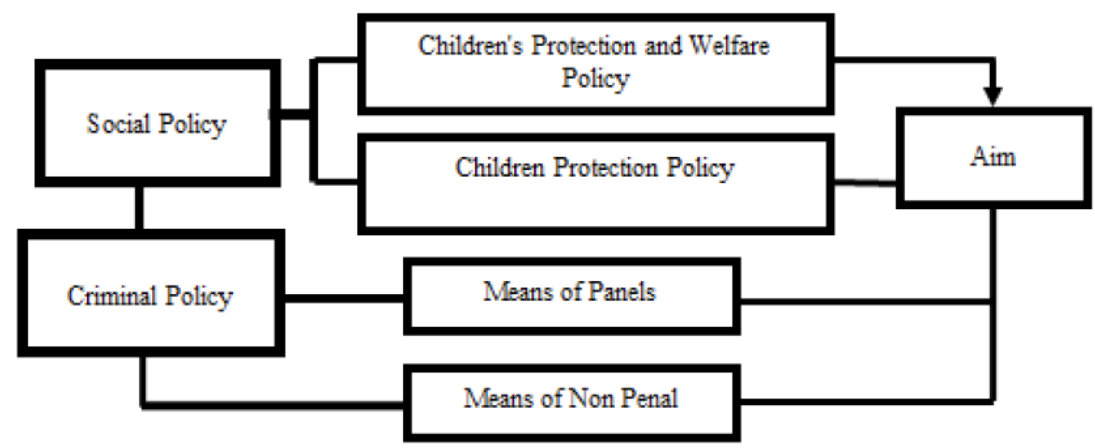

Figure 1: Penal and Non Penal Approach.

as the rational organization of the control of crime by society. The politics of criminal law in overcoming crime is part of social policy to achieve the protection and welfare of the community, especially protection against child. Thus, in terms of social policy, according to Arief (2016) law enforcement through criminal policy is a rational effort in crime prevention carried out through political/criminal policy by using criminal law enforcement (means of punishment) and facilities outside of criminal law (non-penal). Criminal policy is part of a community protection policy (social defense policy) which, together with a community welfare policy, is part of a social policy.

Efforts to eradicate crime with a criminal policy that includes the use of penal and non-penal means are part of the criminal law enforcement effort. Thus the politics or criminal law policy is also part of the law enforcement policy. Criminal policy can be implemented with a criminal law policy (penal policy) and nonpenal policy (nonpenal policy). According to Jaya (2008), a policy by means of penalties means that it must determine policies regarding formulation, acts which constitute criminal acts; application that fulfills the meaning, how the application of the criminal provisions; and executions which have the meaning of criminal implementation which has been applied. Criminal policies with non-familiar means among others implemented by applying the provisions of administrative law and civil law. More specifically, the relationship between social and criminal policies aimed at the protection and welfare of children can be seen in the following scheme (Hadisuprapto et al., 2008):

Criminal policy using non-penal means is important to put forward in the completion of marriage. The use of this approach emphasizes aspects of improving conditions that have a direct or indirect influence on the onset of child marriage. In the global development, the use of ways to resolve cases of children outside the formal channels has been included in the agenda of discussion at the international level, namely through the 9th UN Congress 1995, the 10th 2000 UN Congress and the International Penal Reform Conference International Conference 1999.The international meeting encouraged the emergence of three international documents relating to the issue of restorative justice and mediation in criminal cases, namely The Recommendation of the Council of Europe 1999 No. R (99) 19 concerning Mediation in Penal Matters, The EU Framework Decision 2001 concerning the Standing of Victims in Criminal Proceedings; (EU 2001/220/JBZ) and The UN Principles 2002 (Ecosoc Resolution 2002/12) on Basic Principles on the Use of Restorative Justice Programs in Criminal Matters.

\section{CONCLUSION}

The child marriage issue in many countries in the world is a multi-factor and complicated problem, because it involves issues such as cultural - public, economic, religious and law (criminal). Based on data survey from the Indonesian Democracy and Health ((Demokrasi dan Kesehatan Indonesia (SDKI), 17 percent of women aged between 20-24 who have ever been married were married before the age of 18 . From many studies, child marriage has a negative impact on children in addition to violating children's rights. The various factors that cause child marriage as described above, can be said to be a symptomatic causal that requires a therapeutic method to overcome it. This causal symptom indicates that the problem of child marriage does not only occur in the jurisdiction of the state as a product of state policy in a set of values and norms of criminal law, but is also related to non-legal / non-penal issues. Thus, theoretically, it is important and very possible to combine the two penal and nonpenal approaches as a comprehensive and integral policy approach in dealing with child marriage.

Judging from the current penal context, legal protection for children who are married off only stops 
until the consequences are received in the construction of a criminal offense, for example the provisions in Article 288 of the Criminal Code which require injury, serious injury or death, so it is not the act of marriage children, or in other words, there are no rules that clearly and expressly prohibit and threaten the act of marrying off children, whether committed by the child's parents, guardian or family. Likewise, the rule of law on the child protection of law, which threaten acts that have indications of neglect, threats - violence and exploitation of children. Therefore, the formulation of the prohibition against the act of marrying off children is part of the politics of criminal law, namely forming a new legal norm for the act of marrying off children. In other words, the act of marrying off children can be criminalized with certain considerations. Carrying out a criminal law policy by establishing a new act is intended not only to warn everyone against the prohibition of child marriage, but more than that so that children are protected from the child marriage. The central problem in criminal policy using the penal means as stated above is: 1.) Determine what actions should be into the criminal act of child marriage. neglect of obligations and responsibilities, including not preventing child marriage, is one of the norm's substantive parameters; 2 . Determine what sanctions are otherwise used or imposed on the offender who has marries the child.

The penal approach can also be done with Regional Regulations, Governor Regulations, Regent Regulations which are products of regional legislation that are able to accelerate the reduction in the number of child marriages. Regional Regulations have legal instruments that can ensure compliance with prohibitions and / or implementation of government programs. Thus the Regent Regulation also has the power to force each sector in the government apparatus to carry out their respective functions so that there is an integrated movement to eradicate and or reduce the number of child marriages. A similar policy demands commitment from every local government that has a high number of child marriages in Indonesia.
Judging from the non-penal context, it is necessary to build a Child Friendly / Child Friendly Village Model. This model is a Pilot Guidance model by selecting an area or village that has a high rate of child marriage. This kind of policy is part of the regional government as a quick step with which results can be seen. The integrity kind of this program is not only interpreted as a program that requires the involvement of all government and community components as well as the target of guidance, namely parents and children in the region, it also has an integral meaning in integrating program content, which is related to sectors that are urgent to be empowered, such as physical and spiritual education community, thinking of cultural and attitudes also the family economy.

\section{REFERENCE}

Arief, B. N. (2008). The criminal law policy is the development of the drafting of a new Penal Code. Jakarta: Kencana Prenada Media Group.

Arief, B. N. (2011). Anthology of Criminal Law Policy (Development of the Drafting of the New Criminal Code Concept).

Arief, B.N. (2016). Anthology of criminal law policy. Prenada Media.

Arivia, G. (2005). Potret Buram Eksploitasi Kekerasan Seksual pada Anak. Jakarta: Ford Foundation.

Central Bureau of Statistics\& UNICEF. (2016). Kemajuan yang tertunda: analisis data perkawinanusiaanak di Indonesia. Jakarta: Central Bureau of Statistics

Hadisuprapto, P., Wahyudi, S., Setyorini, Y., \& Basuki, I. (2008). Children's delinquency: understanding and handling it. Bayumedia Publishing.

Jaya, N. S. P. (2008). Some thoughts towards the development of criminal law. Citra Aditya Bakti.

Muangman, D. (1980). Report on AKAP Study of 1,000 Thai Masseuses Concerning Family Planning, Pregnancy and Abortion, Venereal Disease Infections, and Narcotic Addiction. Faculty of Public Health Mahidol University.

Santrock, J. W. (2003). Adolescence of adolescent development. Jakarta: Erlangga.

Saraswati, R. (2009). Child protection law in Indonesia. Citra Aditya Bakti.

Sudarto, K. S. H. P. (1981). Penalty Issues and Correctional Ideas. Bandung: Alumni.

Sudarto. (1983). Criminal law and community development: a review of criminal lawre forms. Sinar Baru.

DOI: https://doi.org/10.6000/1929-4409.2021.10.07

() 2021 Sri Ismawati; Licensee Lifescience Global.

This is an open access article licensed under the terms of the Creative Commons Attribution Non-Commercial License (http://creativecommons.org/licenses/by-nc/3.0/) which permits unrestricted, non-commercial use, distribution and reproduction in any medium, provided the work is properly cited. 